\title{
Criminalization and the Collateral Consequences of Conviction
}

\author{
Zachary Hoskins ${ }^{1}$
}

Published online: 28 October 2017

(c) The Author(s) 2017. This article is an open access publication

\begin{abstract}
Convicted offenders face a host of so-called "collateral" consequences: formal measures such as legal restrictions on voting, employment, housing, or public assistance, as well as informal consequences such as stigma, family tensions, and financial insecurity. These consequences extend well beyond an offender's criminal sentence itself and are frequently more burdensome than the sentence. This essay considers two respects in which collateral consequences may be relevant to the question of what the state should, or may, criminalize. First, they may be relevant according to specific accounts of criminalization, including plausible versions of the harm principle and legal moralism. Second, they may be relevant to the legitimacy of state criminalization more generally. Thus for legal theorists concerned with the issue of legitimate criminalization, normative questions raised by collateral consequences are of central importance.
\end{abstract}

Keywords Criminalization · Collateral consequences · Punishment · Harm principle $\cdot$ Legal moralism · Political legitimacy

In his seminal book Overcriminalization, Douglas Husak contends that the central objection to too much criminal law is that it leads to too much punishment. ${ }^{1}$ But punishment is not the only consequence of a criminal conviction. Convicted offenders also face a host of so-called "collateral" consequences: formal measures such as legal restrictions on voting, employment, housing, or public assistance, as well as informal

\footnotetext{
${ }^{1}$ Douglas Husak, Overcriminalization: The Limits of the Criminal Law (Oxford: Oxford University Press, 2008), p. 3.
}

Zachary Hoskins

zachary.hoskins@nottingham.ac.uk

1 University of Nottingham, Room C09 Humanities, University Park, Nottingham NG7 2RD, UK 
consequences such as stigma, family tensions, and financial insecurity. ${ }^{2}$ These consequences extend well beyond an offender's criminal sentence itself and are frequently more burdensome than the sentence. In this essay, I consider the relevance of these collateral consequences for criminalization.

One straightforward way in which collateral consequences are relevant to criminalization is that they constitute one of the wrongs of overcriminalization. That is, just as Husak notes that too much criminal law leads to too much punishment, so too does it lead to too many burdensome collateral consequences. We might grant this claim but think that this is as far as collateral consequences' relevance to criminalization extends. In particular, even if collateral consequences constitute part of what's wrong with overcriminalization, we might doubt whether they have any implications for determinations of what conduct the state may justifiably criminalize. It may seem, after all, that we should first sort out which types of conduct the state should declare to be criminal violations, and then attend to the question of how society is permitted (or required) to treat those found guilty of such violations.

In what follows, though, I consider two respects in which collateral consequences may be relevant to the question of what the state should, or may, criminalize: briefly, they may be relevant according to our preferred account of criminalization, or they may be relevant to the legitimacy of state criminalization more generally. First, however, I take a closer look at the range of collateral consequences faced by those with criminal convictions.

\section{Varieties of Collateral Consequences}

A criminal conviction typically subjects one to prison or jail time, probation, a fine, or some other formal sentence. But a conviction brings an array of other consequences as well. Some of these are direct products of positive law, whereas others are more or less foreseeable consequences of having a criminal record but are not themselves directly inflicted by restrictive policies. I'll refer to these, respectively, as "legal" and "informal" consequences. ${ }^{3}$

Some informal consequences flow directly from the punishment itself. Incarceration, for example, frequently results in lost wages, and it can have damaging effects on offenders' relationships with family members, friends, and others in the community. Incarceration takes offenders away from their partners and other family members, which may lead to tensions (especially if the offender generated household income) or simply estrangement, such as between an incarcerated parent and her child.

There is also substantial social stigma associated with having a criminal record. This stigma can manifest in the decisions of employers or landlords to deny jobs or housing, respectively, to offenders (as I discuss below, in some cases such decisions may be explicitly authorized by legal policies). The stigma of a criminal record can also, as Wayne Logan notes, "function to disrupt or sever social ties that can be key to finding employment." ${ }^{4}$ What's worse, numerous offenders, particularly those with convictions for sexual offenses, have been murdered, assaulted, or otherwise harassed by other community members. ${ }^{5}$

\footnotetext{
${ }^{2}$ See Zachary Hoskins, "Ex-offender Restrictions," Journal of Applied Philosophy 31(1) (2014): 33-48.

${ }^{3}$ There is often significant interplay between legal and informal consequences. For example, many informal consequences, such as discrimination by prospective employers, are facilitated by legal policies making criminal records widely accessible.

${ }^{4}$ Wayne Logan, “Informal Collateral Consequences," Washington Law Review 88(3) (October 2013): 1103-1117, p. 1108.

${ }^{5}$ Wayne Logan, Knowledge as Power: Criminal Registration and Community Notification Laws in America (Stanford: Stanford University Press, 2009), pp. 126-127.
} 
Offenders also face a host of legal restrictions (I focus in this essay on the U.S. context; similar sorts of restrictions can be found in other countries, although the scope and severity of restrictions is consistently greater in the United States). Numerous state policies bar, or expressly permit state licensing agencies to bar, people with various types of criminal convictions from certain types of employment. Vocations that are restricted under various state statutes include accountant, police officer, teacher, architect, barber, cosmetologist, roofer, chiropractor, plumber, interior designer, land surveyor, and farm labor contractor. ${ }^{6}$ In many states, private or public employers or licensing agencies are even permitted to consider arrests that never led to conviction when making hiring decisions. ${ }^{7}$

In addition to employment restrictions, federal regulations permit local public housing authorities to deny housing to prospective tenants with criminal histories. Various state and municipal laws bar people convicted of sexual offenses from living near schools, parks, or other places where children are frequently present. ${ }^{8}$ Federal law and many state laws permit the involuntary civil commitment of sex offenders who have completed their sentences but are believed still to be sexually dangerous. ${ }^{9}$ Federal law permanently bars those with drug-related felony convictions from receiving welfare assistance (the law allows states to opt out of the lifetime ban or to modify it, which some but not all states have done). ${ }^{10}$ Forty-eight states impose some level of voting restrictions on offenders, and in several states, offenders may be permanently disenfranchised. ${ }^{11}$ Other policies place restrictions on fostering or adopting children, ${ }^{12}$ obtaining driver's licenses, ${ }^{13}$ serving on juries, ${ }^{14}$ securing federal student loans, ${ }^{15}$ possessing firearms, ${ }^{16}$ serving in the military, ${ }^{17}$ or playing certain video games. ${ }^{18}$ Noncitizen offenders may be deported. ${ }^{19}$ Offenders often are legally required to pay a variety of fees related to the costs of their incarceration, to their supervision while on parole or probation, or to the state's costs in prosecuting them;

\footnotetext{
${ }^{6}$ See the National Inventory of the Collateral Consequences of Conviction (NICCC), a project of the American Bar Association, available online at www.abacollateralconsequences.org/. See also Lisa Riordan Seville, "Got a Criminal Record? Please Go Away," The Crime Report (March 21, 2011), available online at www.thecrimereport.org/archive/2011-03-got-a-criminal-record-please-go-away.

7 See “After Prison: Roadblocks to Reentry (2009 update)," Legal Action Center report (2009), p. 10. Available online at www.lac.org/roadblocks-to-reentry/upload/lacreport/Roadblocks-to-Reentry-2009.pdf.

8 See Corey Rayburn Yung, "Banishment by a Thousand Laws: Residency Restrictions on Sex Offenders," Washington University Law Review 85(1) (2007): 73-99. See also NICCC op cit.

9 For the federal law, see 18 U.S.C. $§ 4248$. For a list of states with such laws, see Association for the Treatment of Sexual Abusers, "Civil Commitment of Sexually Violent Predators," available online at www. atsa.com/civil-commitment-sexually-violent-predators.

1021 U.S.C. $\$ 862 \mathrm{a}$ (a).

11 ProCon.org, "State Felon Voting Laws," available online at http://felonvoting.procon.org/view.resource. php?resourceID=000286.

12 Adoption and Safe Families Act (P.L. 105-189), 111 Stat. 2155 (1997).

13 E.g., C.R.S. 42-2-125(1); 625 ILCS 5/6-103; N.M. Stat. Ann. § 66-5-5.

14 E.g., 28 U.S.C. $\S$ 1865(b)(5); ARK. CODE ANN. § 16-31-102(a)(4); DEL. CODE ANN. tit. 10, § 4509(b)(6).

1520 U.S.C. $\$ 1091(r)(1)$.

16 E.g., Cal. Pen. Code $§ 29800$; Minn. Stat. $\$ 609.165$ subd. 1a-1b.

1710 U.S.C. $\$ 504$.

18 Don Reisinger, "Here's How New York is Responding to Sex Offenders Playing Pokémon Go," Fortune (August 1, 2016), available online at http://fortune.com/2016/08/01/ny-sex-offenders-pokemon-go/.

198 U.S.C. $\$ 1227(\mathrm{a})(2)(\mathrm{B})(\mathrm{i})$.
} 
many states even require defendants' to pay fees for their public defenders. These fees themselves may in turn be subject to interest, surcharges, or collection fees. ${ }^{20}$

These legal measures are collateral consequences in the sense that, at least in current legal practice, they are typically not treated as part of an offender's formal punishment but rather as civil or administrative measures. A number of scholars have argued, however, that they are in fact additional forms of punishment and should be treated as such. ${ }^{21}$ In addition, there has been some indication in recent years that courts are becoming more skeptical about this distinction. ${ }^{22}$ I only note this debate here, but later I discuss ways in which it might matter, for our central question, whether collateral restrictions are regarded as forms of punishment or as civil measures.

In the next two sections, I consider two respects in which the existence of collateral consequences may be relevant to the question of justifiable criminalization policy. The first emerges from an examination of the two predominant principles of criminalization: the harm principle and legal moralism. The second derives from considerations of state legitimacy more generally.

\section{Collateral Consequences, the Harm Principle, and Legal Moralism}

The harm principle was most famously articulated by J.S. Mill, who wrote that "the only purpose for which power can rightfully be exercised over any member of a civilised community against his will is to prevent harm to others." 23 Others have offered similar articulations of the principle. Joel Feinberg, for example, writes that "it is always a good reason in support of penal legislation that it would be effective in preventing ... harm to persons other than the actor." 24

Theorists commonly, and reasonably enough, interpret the harm principle as holding that the state may only interfere with actions that themselves cause or risk harm to others. A.P. Simester and Andreas von Hirsch characterize the view as holding that "the state is justified in intervening coercively to regulate conduct only when that conduct causes or

${ }^{20}$ See Alexes Harris, Heather Evans, and Katherine Beckett, "Drawing Blood from Stones: Legal Debt and Social Inequality in the Contemporary United States," American Journal of Sociology 115(6) (2010): 1753-1799, p. 1758; Alicia Bannon, Mitali Nagrecha, and Rebekah Diller, "Criminal Justice Debt: A Barrier to Reentry," a report of the Brennan Center for Justice, New York University School of Law (2010), esp. pp. 7-10, available online at www.brennancenter.org/publication/criminal-justice-debt-barrier-reentry; Adam Liptak, "Debt to Society is Least of Costs for Ex-Convicts," The New York Times (February 23, 2006), available online at www.nytimes.com/2006/02/23/national/23fees.html?pagewanted=all.

21 See, e.g., Jeremy Travis, "Invisible Punishment: An Instrument of Social Exclusion," in Marc Mauer and Meda Chesney-Lind (eds.), Invisible Punishment: The Collateral Consequences of Mass Imprisonment (New York: The New Press, 2003), pp. 15-36; Margaret Colgate Love, "The Collateral Consequences of Padilla v. Kentucky: Is Forgiveness Now Constitutionally Required?," University of Pennsylvania Law Review PENNumbra 160 (2011): 113-127, esp. p. 121; and Margaret Fitzgerald, "The Control Continuum: Analysing the Scope and Impact of Post-Release Measures for Offenders," Judicial Studies Institute Journal 1 (2010): 31-32.

22 See, e.g., US v. Nesbeth, No. 15-cr-18 (E.D.N.Y May 25, 2016); Joanna Rosenberg, “A Game Changer? The Impact of Padilla v. Kentucky on the Collateral Consequences Rule and Ineffective Assistance of Counsel Claims," Fordham Law Review 82(3) (2013): 1407-1445; and Margaret Colgate Love, ibid.

23 J.S. Mill, On Liberty (London: Parker, 1859), ch. 1, para. 9.

24 Joel Feinberg, Harm to Others (New York: Oxford University Press, 1984), p. 26. An important difference between Mill's and Feinberg's articulations is that Mill's makes the prevention of harm a necessary condition of criminalization, whereas Feinberg's does not. 
risks harm to others." ${ }^{25}$ Douglas Diekema writes that "[t]he characteristic of parental decision-making that justifies [state] interference is ... that the decision poses some harm to the child." 26 And Richard Epstein writes, "Where an individual undertakes a course of action that causes no harm to another person, that conduct ... generates no liability under the civil or criminal law." ${ }^{27}$ On this understanding of the principle, it seems that collateral consequences have little relevance to questions of criminalization. Criminalization decisions should be based on whether the conduct in question causes or risks harm to others. It is a further, distinct normative question how the state, and society more generally, may treat those convicted of crimes.

Antony Duff and Sandra Marshall have, however, recently highlighted two different interpretations of the harm principle-or to be more precise, they argue that there are in fact two distinct harm principles. ${ }^{28}$ The first, which they call the "Harmful Conduct Principle" (HCP), is the principle essentially expressed by Simester and von Hirsch, Diekema, and Epstein. It holds that "we have good reason to criminalise a given type of conduct if (and only if) it is harmful to others." ${ }^{29}$ By contrast, Duff and Marshall contend that Mill's classic formulation and Feinberg's more recent version are more faithfully represented by what they term the "Harm Prevention Principle" (HPP): "we have good reason to criminalise a given type of conduct if (and only if) doing so will efficiently prevent harm to others." 30

Insofar as criminalizing conduct that is itself harmful will in many cases be an efficient way of preventing harm to others, the two principles, HCP and HPP, will often render the same conclusions in particular cases. But the two principles will not always agree. In some cases, HPP may permit criminalization ${ }^{31}$ where HCP would not (or at least not clearly so). One category of such cases discussed by Duff and Marshall involves accumulative harm: these are cases "when the prospective harm will be significant enough to warrant the criminal

\footnotetext{
25 A.P. Simester and Andreas von Hirsch, Crimes, Harms, and Wrongs: On the Principles of Criminalisation (Oxford: Hart Publishing, 2011), p. 35.

26 Douglas S. Diekema, "Parental Refusals of Medical Treatment: The Harm Principle as Threshold for State Intervention," Theoretical Medicine and Bioethics 25(4) (2004): 243-264, p. 250.

27 Richard A. Epstein, "The Harm Principle-and How It Grew," University of Toronto Law Journal 45(4) (1995): 369-417, p. 369.

28 See R.A. Duff and S.E. Marshall, “'Abstract Endangerment,' Two Harm Principles, and Two Routes to Criminalisation," Bergen Journal of Criminal Law and Criminal Justice 3(2) (2015): 131-161. For a similar distinction, see Victor Tadros, "Harm, Sovereignty, and Prohibition," Legal Theory 17(1) (2011): 35-65. 29 Ibid., p. 135.

30 Ibid., pp. 134-135. See also John Gardner and Stephen Shute, “The Wrongness of Rape," in John Gardner, Offences and Defences: Selected Essays in the Philosophy of Criminal Law (Oxford: Oxford University Press, 2007), pp. 1-32. As the parentheses in HCP and HPP indicate, Duff and Marshall are primarily concerned with the two principles as providing positive reasons to criminalize (i.e., the "if" clause), rather than with providing constraints on what may be criminalized (i.e., the "only if" clause). Indeed, their subsequent discussion omits the "only if" clause from each principle. In my view, by contrast, the "only if" clause is crucial. Without it, the principles tell us what constitutes one good reason to criminalize, but this is consistent with there being any number of other good reasons to criminalize. I believe we do better to read the harm principle, in any of its versions, as setting a constraint on what could constitute a reason to criminalize. This is consistent with Mill's classic formulation of the principle ("the only purpose for which power can rightfully be exercised ...is to prevent harm to others," op cit., emphasis added). It is also, in my view, more consistent with the spirit of the principle generally, as setting limits on the state's intrusion into citizens' lives. Given that the "and only if" clause is central, not parenthetical, to the principle, in what follows I retain it but omit the parentheses.

31 To be precise, Duff and Marshall argue for a two-step line of reasoning from, first, HPP as a basis for state regulation of behavior to, second, criminalization of breaches of regulations. See ibid., pp. 148-149.
} 
law's attention, or (in the case of threshold harm) will ensue at all, only if many people engage in the relevant conduct." 32 They discuss the example of water pollution: "If enough people dispose of their garbage in the river, there will be a real threat to health; but if only I do it, there will be no such threat." ${ }^{33}$ It is difficult to explain how such conduct might be criminalized according to HCP, but it is relatively straightforward to justify its criminalization via HPP.

In other cases, even if some type of conduct is itself harmful (or harm-risking) to others, and thus criminalizable under $\mathrm{HCP}$, it may also be the nature of the conduct that a criminal prohibition would be practically infeasible to enforce. A 2015 French ban on the use of headphones for telephone conversations while driving focused on the risks of harm to others created by distraction and sensory deprivation. The law, however, excluded the use of smart watches and Bluetooth systems integrated into vehicles, not because smart watches and Bluetooth systems did not create similar risks, but because enforcing a ban on the use of these technologies would be "virtually impossible." ${ }^{34}$ If the infeasibility of enforcement in this case meant that criminalizing the conduct would not efficiently prevent harm to others, then this would be a case of conduct that, although it creates the risk of harm to others, is not criminalizable according to HPP. But notice that even if some criminal prohibition is, as a practical matter, infeasible to enforce, criminalization might still help to prevent (or at least reduce) harm to others. Those who emphasize the expressive role of the criminal law in condemning certain conduct might see a harmreductive role for (even practically unenforceable) criminalization if the criminalization itself reinforced social norms or helped to educate the general public about the wrongness of the harmful conduct. ${ }^{35}$ If, however, the criminalization was both practically unenforceable and had no harm-reducing expressive function, then it would not be justified according to HPP, even if (because the conduct itself was harmful) it was justified on HCP.

HPP, then, rules out criminalization in cases when it would not efficiently prevent harm to others. What about cases, however, in which criminalization would prevent harm to others, but it would also contribute to harms that would outweigh the harms it would prevent? Many advocates of decriminalizing drugs, for example, claim that criminalization causes more harm than it prevents. ${ }^{36}$ HPP tells us only that we have good reason to

\footnotetext{
32 Ibid., p. 146.

33 Ibid.

34 "La Sécurité Routière nous répond à propos des smartwatches au volant," iphonote.com (April 17, 2015), available online at www.iphonote.com/actu/78709/la-securite-routiere-nous-repond-a-propos-des-smartwatchesau-volant.

35 On the educative message of the criminal law, see, e.g., Jean Hampton, "The Moral Education Theory of Punishment," Philosophy and Public Affairs 13(3) (1984): 208-238; and A.C. Ewing, "Punishment as Moral Agency: An Attempt to Reconcile the Retributive and the Utilitarian View," Mind 36(143) (July 1927): 292-305. Others who emphasize the expressive role of the criminal law might contend, in favor of HCP over HPP, that there is still good reason in some cases to criminalize conduct that is harmful or harmrisking to others regardless of whether doing so would help to reduce harm. Expressing condemnation of such conduct is valuable in its own right, they might argue, regardless of its efficacy in reducing harm. I am skeptical of the expressive value of criminalizing harmful conduct if the value cannot be traced ultimately back to its role in preventing (or at least reducing) harm. But even if there is a non-harm-reductive expressive value to such criminalization, I doubt it carries much weight when considered against the significant harms to which criminalization contributes.

36 See, e.g., Peter Reuter, The Unintended Consequences of Drug Policies, Rand Corporation report, (Utrecht: Trimbos Institute, 2009); Antonio Maria Costa, "How many lives would have been lost if we didn't have controls on drugs?," Guardian (September 19, 2009); Douglas N. Husak, "Guns and Drugs: Case Studies on the Principled Limits of the Criminal Sanction," Law and Philosophy 23(5) (2004): 437-493, esp. p. 452; Ethan Nadelmann, "Drug Prohibition in the United States: Costs, Consequences, and Alternatives," Science 245(4921) (1989): 939.
} 
criminalize conduct $\Phi$ if and only if doing so efficiently prevents harm to others; the principle says nothing about the foreseeable, albeit unintended, harms to which criminalizing conduct $\Phi$ may contribute. But it is difficult to make sense of a principle of criminalization grounded in a fundamental concern for harm reduction that did not also concern itself with the harms that are likely to stem from criminalization. Thus I suggest that the spirit of HPP is better reflected in a formulation that takes account both of harms to others that may be prevented (or reduced) by criminalization and of harms to which criminalization may contribute. It would be too demanding to ask those making criminalization decisions to anticipate all of the potential harms that may stem from criminalization (or all of the potential harms it may prevent, for that matter). But if we focus on foreseeable harms, then we arrive at the following modified formulation:

(HPP2) We have good reason to criminalize a given type of conduct if and only if doing so will contribute to a net reduction in foreseeable harm to others.

HPP2 still tells us, as HCP does not, that we have good reason to criminalize in cases when the given conduct is not itself harmful but may play a contributing role to some further harm being done, such as in the water pollution example (notice that HPP2 does not require criminalization in such cases; there may be defeating or overriding reasons against criminalization). But HPP2 rules out criminalization, as HPP does not clearly do, in cases when the harms to which criminalization would foreseeably contribute outweigh the harms it would foreseeably prevent. In my view, HPP2 is thus an improvement on both HCP and HPP.

Feinberg suggests a further amendation (or clarification) of the harm principle. He builds wrongfulness into his version of the principle, specifying that "only setbacks of interests that are wrongs ... are to count as harms in the appropriate sense." ${ }^{37}$ Conduct that sets backs another's interests but does not do so wrongfully-essentially, that does not violate their rights-may not be criminalized. ${ }^{38}$ Similarly, we might amend HPP2 to make clear that the sense of harm with which we are concerned is wrongful harm. Thus WHPP2:

(WHPP2) We have good reason to criminalize a given type of conduct if and only if doing so will contribute to a net reduction in foreseeable wrongful harm to others.

For HPP2, the relevance of collateral consequences to criminalization decisions is relatively clear. Criminalizing some type of conduct means that those who engage in that conduct may be subject, as they were not subject before, to arrest, prosecution, and conviction. And those who are convicted may be subject, in turn, to a host of collateral consequences. These collateral consequences are foreseeably harmful in the sense that they set back offenders' interests (for example, to find employment or housing), and thus they must be factored in when considering whether criminalizing some conduct would contribute to a net reduction in foreseeable harm. ${ }^{39}$

\footnotetext{
37 Feinberg op cit., p. 36. On the relationship of harm and wrongfulness in theories of criminalization, see, e.g., Patrick Tomlin, "Retributivists! The Harm Principle Is Not For You!" Ethics 124(2) (2014): 272-298, pp. 280-282; Duff and Marshall op cit., pp. 139-140; and Husak, Overcriminalization op cit., pp. 71-76. 38 Feinberg, ibid.

39 One might object that HPP2, like other versions of the harm principle, is concerned with harm to others, whereas the central harms of collateral consequences are borne by the very people who violated the laws. Classic articulations of the harm principle make clear, however, that the "to others" qualification is intended as a protection against paternalistic impositions of coercive state power. In other words, the point is that the state may not rightfully restrict people's liberties in order to prevent their autonomously acting in ways that are harmful only to themselves. But the harms of collateral consequences are not self-inflicted by offenders; they are imposed on offenders by the state. Thus it is not inconsistent to accept the harm principle's
} 
The relevance of collateral consequences for WHPP2 is more complicated. Although these consequences are harmful in the bare sense of setting back the interests of those subject to them, it is less clear whether they constitute wrongful harms. Answering this question requires a normative analysis of collateral consequences themselves. Which collateral consequences, if any, are morally justifiable? Here the question, noted earlier, of whether collateral consequences are best regarded as forms of punishment becomes centrally relevant. ${ }^{40}$ Treatment that is justifiable as punishment may not be justifiable in other contexts. ${ }^{41}$ Thus in assessing whether those consequences that we regard as forms of punishment constitute wrongful harms, the salient question is whether they accord with whichever principles we believe should govern the practice. Those who characterize (and object to) collateral consequences as additional measures of punishment typically have in mind legal restrictions on employment, housing, the vote, or other goods. These critics commonly argue that the restrictions, because they are not formally incorporated into the sentencing process, violate a number of legal safeguards on punishment (double-jeopardy protection, notification requirements, and proportionality). ${ }^{42}$ Alternatively, critics might charge that various restrictions are inconsistent with their preferred rationale for punishment: deterrence, retribution, education, or something else. Or they might charge that at least some of the restrictions violate some moral constraints on punishment, such as that punishment should not tend to undermine offenders' prospects of reform. ${ }^{43}$ Insofar as collateral restrictions are inconsistent with the principles or values that rightly govern punishment, then they will constitute wrongful harms and would be relevant to WHPP2.

For those collateral consequences that we do not regard as forms of punishment, we must look elsewhere to determine whether they constitute wrongful harms. We could ask whether the various harms are deserved, whether those subject to them have forfeited their rights against such harms, whether the harms serve some overridingly valuable social purpose, etc. ${ }^{44}$ In considering these questions, the distinction between legal and informal collateral consequences is arguably relevant. It is one question whether a person is wrongfully harmed if she experiences, for example, family tensions, financial strain, or social disapproval; it is another question whether she is wrongfully harmed if she is denied equal protection under the law.

Footnote 39 continued

prohibition on paternalistic harm prevention by the state while also admitting the relevance to the harm principle of the harms associated with collateral consequences.

${ }^{40}$ See Zachary Hoskins, "Collateral Restrictions," in Chad Flanders and Zachary Hoskins (eds.), The New Philosophy of Criminal Law (London: Rowman Littlefield International, 2016), pp. 249-265.

41 David Boonin describes the problem of punishment as that of justifying treating those who have violated the law "in ways that would otherwise be impermissible." Boonin, The Problem of Punishment (Cambridge, U.K.: Cambridge University Press, 2008), p. 1.

42 See, e.g., Jenny Roberts, "The Mythical Divide between Collateral and Direct Consequences of Criminal Convictions: Involuntary Commitment of 'Sexually Violent Predators,'” Minnesota Law Review 93(2) (2008-2009): 670-740; Michael Pinard, "An Integrated Perspective on the Collateral Consequences of Criminal Convictions and Reentry Issues Faced by Formerly Incarcerated Individuals," Boston University Law Review 86(3) (2006): 623-690; Gabriel J. Chin, "The New Civil Death: Rethinking Punishment in the Era of Mass Conviction," University of Pennsylvania Law Review 160 (2012): 1789-1833; Gabriel J. Chin and Richard W. Holmes, Jr., "Effective Assistance of Counsel and the Consequences of Guilty Pleas," Cornell Law Review 87 (2002): 697-742.

43 See Zachary Hoskins, Beyond Punishment? A Normative Account of the Collateral Consequences of Conviction (New York: Oxford University Press, forthcoming), ch. 4.

44 For a normative analysis of legal collateral consequences considered not as forms of punishment but as civil measures, see Hoskins, "Ex-offender Restrictions," op cit. 
My aim here is not to provide a full account of which collateral consequences, in which circumstances, constitute wrongful harms. But it is obvious that informal consequences such as murder, assaults, and harassment of offenders qualify. I argue elsewhere that many legal restrictions-e.g., lifetime voting bans on broad classes of offenders-are unjustifiable in their current forms, and that others-restrictions on welfare assistance or student loans, for example - are unjustifiable in any form, whether as punishment or as civil measures. ${ }^{45}$ Scholars have also raised general concerns about collateral consequences due to their racially disparate impacts. ${ }^{46}$ Whatever our answer to the question of which (if any) collateral consequences constitute wrongful harms, however, the point here is just that this answer will be relevant to criminalization decisions grounded in a plausible formulation of the harm principle, one which takes into account not only the wrongful harms to be prevented by criminalization but also the wrongful harms to which criminalization would foreseeably contribute. (And again, if we reject the incorporation of wrongfulness into the principle and opt for HPP2 instead, then all collateral consequences, insofar as they are harmful, will be relevant to criminalization decisions).

Would collateral consequences be relevant on theories of criminalization other than the harm principle? In the remainder of this section, I consider the harm principle's most prominent competitor: legal moralism. For legal moralism, criminalization is justified not because it helps to prevent, or reduce, harms or risks of harm, but because the conduct criminalized is wrongful. As with the harm principle, articulations of legal moralism have varied somewhat. Carl Cranor, for example, describes it this way: "the immorality of a particular form of conduct provides a reason, but not a sufficient [or necessary] reason for making it illegal." ${ }^{47}$ On Michael Moore's stronger articulation, by contrast, legal moralism holds that "the immorality of behaviour ... will be a sufficient condition with which to justify criminal legislation." 48 Generally, though, as Duff puts it, legal moralism holds that "the justification for criminalizing a given type of conduct depends on the moral wrongfulness of that type of conduct." 49

It might seem that we could draw a similar distinction with legal moralism to the one we drew with the harm principle: that is, we could differentiate what we could call a "Wrongful Conduct Principle" (WCP) from a "Wrong Prevention Principle" (WPP):

(WCP) We have good reason to criminalize a given type of conduct if and only if it is wrongful.

\footnotetext{
45 Hoskins, Beyond Punishment? op cit.

46 See, e.g., Michelle Alexander, The New Jim Crow: Mass Incarceration in the Age of Colorblindness (New York: The New Press, 2010); and Anthony C. Thompson, Releasing Prisoners, Redeeming Communities: Reentry, Race, and Politics (New York: New York University Press, 2009).

47 C.F. Cranor, "Legal Moralism Reconsidered," Ethics 89(2) (1979): 147-169, p. 147. Generally, see Thomas Søbirk Petersen, "What is Legal Moralism?," SATS: Northern European Journal of Philosophy 12(1) (2011): 80-88.

48 Michael Moore, Placing Blame: A General Theory of the Criminal Law (Oxford: Clarendon Press, 1997), p. 645 .

49 R.A. Duff, “Towards a Modest Legal Moralism," Criminal Law and Philosophy 8(1) (2014): 217-235, p. 217.
} 
(WPP) We have good reason to criminalize a given type of conduct if and only if doing so will efficiently prevent wrongs to others.

If we then further modified WPP to consider foreseeable wrongs to which criminalization could contribute, then we would have WPP2:

(WPP2) We have good reason to criminalize a given type of conduct if and only if doing so will contribute to a net reduction in foreseeable wrongs to others.

Insofar as some, perhaps all, collateral consequences are unjustifiable, they will count among the foreseeable wrongs to which increased criminalization will contribute. Thus questions of collateral consequences' moral justification might appear to be relevant to WPP2 in essentially the same way they are relevant to WHPP2.

If legal moralism differed from the harm principle only about whether the locus of concern in criminalization decisions was harms or wrongs, then the line of reasoning in favor of WHPP2 for harm principle adherents would similarly count in favor of WPP2 for legal moralists. But legal moralism differs from the harm principle not only about the locus of concern but also about how we should deal with that concern. For the harm principle, in its standard articulations, the correct way to deal with harms is to try to prevent them (whether the harmful criminalized conduct itself or further harms to which the criminalized conduct is likely to contribute). For legal moralism, by contrast, the right way to deal with wrongs is somewhat more complicated. Consider, for example, Moore's description of his version of legal moralism:

[B]ecause it is intrinsically good that culpable wrongdoers get their just deserts (retributivism), and because that good may permissibly be achieved only if wrongs are legislatively proscribed (legality), then prima facie all moral wrongs should be criminalized. $^{50}$

Alternatively, Duff, who describes his version of legal moral as more modest than Moore's, writes:

In a liberal republic of the kind in which we should aspire to live, the distinctive role of the criminal law is to define those wrongs for which we will be publicly called to answer by our fellow citizens, and to provide the formal, institutional mechanisms through which we can thus be called. ${ }^{51}$

Moore's and Duff's accounts of legal moralism differ in significant ways, but what their views share, and what characterizes legal moralism generally, is the conviction that the criminal law is centrally concerned with properly responding to wrongs, rather than preventing or reducing them. For Moore, the proper response is to mete out just deserts for wrongdoing; for Duff, it is to call individuals to answer for wrongdoing (and to hold accountable, through punishment, those found guilty). For legal moralism, meting out just deserts or calling individuals to answer for wrongdoing is not justified instrumentally, by the valuable consequences this promotes. Rather, such a response is itself intrinsically justified in virtue of the wrongfulness of the conduct. This means, though, that the conduct that is criminalized - the conduct for which we may receive just deserts or be held accountablemust itself be wrong. To criminalize conduct that is not itself wrong with the aim of preventing or reducing further wrongdoing would be to mete out just deserts to those who do not

${ }_{50}$ Michael S. Moore, “A Tale of Two Theories,” Criminal Justice Ethics 28(1) (2009): 27-48, p. 31.

51 Duff, “Towards a Modest Legal Moralism,” op cit., p. 222. 
in fact deserve it, or to hold accountable those who have nothing for which to account. This is why legal moralism is articulated by some version of WCP rather than WPP or WPP $2 .{ }^{52}$

Still, an adherent of WCP could also endorse as a side-constraint on criminalization that we should not criminalize wrongful conduct if doing so will contribute to a net increase in wrongs. Again, WCP holds that we have good reason to criminalize a given type of conduct if and only if it is wrongful. This principle makes wrongness of conduct a necessary condition for its criminalization, but it does not make it a sufficient (much less a decisive) condition. It tells us only that if conduct $\Phi$ is wrongful, then we have a good reason to criminalize it; this is consistent with having other reasons, and perhaps overriding reasons, not to criminalize $\Phi$. Moore makes this clear in the passage cited above, when he writes that prima facie all moral wrongs should be criminalized. ${ }^{53}$ Duff describes his legal moralism as more modest than Moore's in the sense that, on his view, not all moral wrongs are even in principle worthy of criminalization; rather, he believes that only some wrongs rise to the level of public concern and thus in principle warrant criminalization. But even among these "public wrongs," Duff clarifies that his legal moralism does not always require criminalization: "it holds only that we have reason to criminalize them, whilst recognising that we might have weightier countervailing reasons either for doing nothing formally, or for preferring legal mechanisms other than that of criminalization." 54

It is thus open to legal moralists to admit as a side-constraint on criminalization that it should not contribute to wrongs substantial enough to outweigh the wrongness of the criminalized conduct itself. Nothing in legal moralism explicitly commits its adherents to this side-constraint, although for a view that takes wrongdoing as its locus of concern, it is a reasonable enough constraining principle. If legal moralists did accept such a constraint, then insofar as criminalizing some conduct $\Phi$ contributed to a state of affairs in which those found guilty of $\Phi$ were subject to wrongful collateral consequences that outweighed the wrong of $\Phi$ itself, criminalizing $\Phi$ would be ruled out.

So, on what I contend is a plausible version of the harm principle, criminalizers would be required to consider whether collateral consequences constitute harms (or perhaps wrongful harms) and to take them into account accordingly in making criminalization decisions. And although legal moralism does not itself require that collateral consequences be considered, it is consistent with a side-constraint grounded in concern about wrongdoing that would require just this. In the next section, I turn to consider another respect in which the existence of collateral consequences may be relevant to the question of what the state may criminalize.

\footnotetext{
52 Duff has suggested that legal moralism in fact has the resources to justify the criminalization of conduct that is not wrongful prior to its legal regulation. Essentially, the strategy is to suggest that there may be compelling reasons to regulate conduct that is not wrongful. Once the conduct is legally regulated, it may in some instances be wrongful to violate the regulations; in such cases, criminalization of this wrongful conduct (the violation of the legal regulations) can be justified by legal moralism. See, e.g., R.A. Duff, Answering for Crime: Responsibility and Liability in the Criminal Law (Portland, Ore.: Hart Publishing, 2007), pp. 89-93; Duff, “Towards a Modest Legal Moralism," op cit., pp. 220-221. See also Duff and Marshall, "Two Harm Principles," op cit., pp. 149-153, on how such a strategy might be used to justify criminalization according to a version of the harm principle that restricts its focus to wrongful harms. The focus of the current discussion, however, is whether, for the legal moralist, the existence of collateral consequences might ever count against criminalizing conduct that is itself wrongful. Thus I set aside the question of whether legal moralism has the resources to criminalize conduct that is not itself (pre-legally) wrongful.

53 Moore, "A Tale of Two Theories," op cit.

54 Duff, “Towards a Modest Legal Moralism,” op cit., p. 230.
} 


\section{Collateral Consequences and the Legitimacy of Criminalization}

We saw in the previous section that collateral consequences may be relevant to particular theories of criminalization. But they may also be relevant in a more general sense, to the state's right to criminalize conduct at all. Criminalization is a paradigmatic state exercise of coercion over its citizens. Philosophical accounts differ regarding what is required for this coercion to be legitimate, but I contend in this section that on two prominent accounts of legitimacy, the existence of collateral consequences may threaten the legitimacy of criminalization altogether.

It is difficult to determine exactly how many people are subject to how many collateral consequences, for a few reasons: as I discussed earlier, many collateral consequences are informal, and as such they are difficult to track. Even focusing on the formal, legal consequences of a conviction, these collateral restrictions are strewn throughout state and federal statutes, regulations, etc., and vary widely in their content, scope, and duration. ${ }^{55}$ Still, a number of recent studies begin to give a sense of the impact. A study published in 2006 found that there were an estimated 16.1 million people in the United States (slightly more than $5 \%$ of the population) who have served or are currently serving sentences for felony convictions. ${ }^{56}$ More specifically, estimates indicate that 6.1 million felons (including those currently serving and those who have completed their sentences) were denied the vote as of $2016 .{ }^{57}$ A 2015 study of the 12 states that (at the time of the study) had adopted the full federal ban on welfare benefits for drug felons estimated that more than 180,000 women in those states may have been denied access to these benefits between 1996 and 2011 (the study did not estimate the number of male felons affected, the impacts in states that implement a modified version of the federal ban, or the impacts of the felony ban on food stamps that was created by the same legislation). ${ }^{58}$

Furthermore, although felons face especially severe restrictions, many restrictions attach to misdemeanors or even arrests as well. So to get a better sense of how many people may be subject to collateral consequences, we should look not solely at felony convictions but at criminal records more generally. ${ }^{59}$ A 2011 report by The National Employment Law

\footnotetext{
55 One report described the various policies as "a national crazy-quilt of disqualifications and restoration procedures." Margaret Colgate Love and Susan M. Kuzma, "Civil Disabilities of Convicted Felons: A State-by-State Survey," U.S. Department of Justice, Office of the Pardon Attorney (October 1996), p. 1.

56 Christopher Uggen, Jeff Manza, and Melissa Thompson, "Citizenship, Democracy, and the Civic Reintegration of Criminal Offenders," Annals of the American Academy of Political and Social Science 605(1) (May 2006): 281-310, on p. 290.

57 Christopher Uggen, Ryan Larson, and Sarah Shannon, "6 Million Lost Voters: State-Level Estimates of Felony Disenfranchisement 2016," report of The Sentencing Project (2016), available online at www.sentencingproject.org/ publications/6-million-lost-voters-state-level-estimates-felony-disenfranchisement-2016/.

58 Marc Mauer and Virginia McCalmont, "A Lifetime of Punishment: The Impact of the Felony Drug Ban on Welfare Benefits," a report of The Sentencing Project (first published 2013; updated 2015), p. 3, available online at http://sentencingproject.org/wp-content/uploads/2015/12/A-Lifetime-of-Punishment.pdf. Some states cited as imposing the full federal ban in Mauer and McCalmont's report have since modified or opted out of the ban. For a more recent list of which states adopt, modify, or opt out of the federal ban, see Maggie McCarthy, Gene Falk, Randy Alison Aussenberg, and David H. Carpenter, "Drug Testing and Crime-Related Restrictions in TANF, SNAP, and Housing Assistance," report of the U.S. Congressional Research Service (R42394; 2016), p. 9, available online at www.fas.org/sgp/crs/misc/R42394.pdf.

59 See "After Prison: Roadblocks to Reentry (2009 update)," report of the Legal Action Center (2009), pp. 8, 12, available online at www.lac.org/roadblocks-to-reentry/upload/lacreport/Roadblocks-to-Reentry2009.pdf.
} 
Project estimated that 65 million U.S. adults have criminal records. ${ }^{60}$ Not everyone with a criminal record is subject to every collateral consequence, of course. But given the wide range of consequences to which those with criminal records may be subject, and the huge number of individuals with criminal records, the potential impact of these policies becomes fairly clear.

As discussed before, all of these collateral consequences are burdensome, and many are arguably wrongful as well. My contention is that the prospect that large portions of the population are subject to what may be wrongful burdens has implications for the legitimacy of the state, and thus its right to coerce its members through criminalization.

One might object that even if the existence of legal collateral restrictions threatens to undermine a state's legitimacy, surely the existence of informal collateral consequences (social stigma, interpersonal discrimination, abuse, etc.) does not do so. After all, the state does not intend informal collateral consequences. But although they may be unintended, these consequences are surely foreseeable. A state's legitimacy may be undermined not only by its infliction of wrongful harms on its members, but also by its unwillingness or inability to protect its members against such harms. ${ }^{61}$ That said, it is true that legal consequences are especially troubling in this regard. After all, through collateral restrictions, the state intentionally subjects large numbers of its members to burdensome measures to which it does not subject others. For political communities grounded in the ideals of liberty and equality, such restrictions should seem especially troublesome. If no adequate justification can be provided for these measures, then it cuts deeply at the state's legitimacy to coerce its citizens through criminalization.

For accounts of political legitimacy grounded in the benefits that the state provides to its members, ${ }^{62}$ a common objection is that even if the state is generally beneficial, it is not beneficial to all of its members; there will inevitably be a significant number of its members for whom the benefits of state coercion are outweighed by the costs-and thus for whom, on this account, state coercion through criminalization would not be legitimate. ${ }^{63}$ This concern is only strengthened when we consider the large numbers of individuals who are subject, in virtue of their criminal records, to legal restrictions on housing, employment, and other goods; social stigma and abuse; financial pressures; and other collateral consequences.

One might offer a Hobbesian line of response here, that even if some fare much worse in a state than others, virtually all will do better than they would do in the state of nature. As Christopher Heath Wellman writes, "an environment with no political state would be an insecure place in which peace would be unavailable and moral rights would be disrespected." ${ }^{64}$ Perhaps, then, even if state subjects many individuals to significant burdens, we should recognize that these individuals are nevertheless, on balance, better off in such a state than out of it. I suspect that those who are denied access to housing, various jobs, and

\footnotetext{
${ }^{60}$ Michelle Natividad Rodriguez and Maurice Emsellem, "65 Million 'Need Not Apply': The Case for Reforming Criminal Background Checks for Employment," report of The National Employment Law Project (March 2011), pp. 3, 27n2.

61 See, e.g., Christopher Heath Wellman, "Rights and State Punishment," The Journal of Philosophy 106(8) (2009): 419-439, p. 435: "[I]f a state is either unable or unwilling to protect its constituents' human rights, then it is illegitimate and has no claim to sovereignty."

62 See, e.g., Mill, On Liberty, op cit.

63 See, e.g., John Rawls, A Theory of Justice (Cambridge, Mass.: Harvard University Press, 1971), p. 175f; and Christopher Heath Wellman, "Liberalism, Samaritanism, and Political Legitimacy," Philosophy and Public Affairs 25(3) (1996): 211-237, pp. 212-213.

64 Wellman, ibid., p. 217.
} 
other goods might at some point begin to doubt whether they are in fact better off than they would be in the state of nature; at least in the state of nature, they might reason, they would be less likely to be systematically denied the opportunity to compete for the goods needed for a decent life. Regardless, this standard (all are better off than they would be in the state of nature) seems to me an unattractively low threshold for political legitimacy, although one's view on this point will presumably depend on one's intuitions about the quality of life in the state of nature. Wellman later writes that "a grossly inefficient or unfair state would be disqualified as too burdensome" to many of its members, and thus illegitimate. ${ }^{65}$ In my view, a state could be grossly unfair in virtue of subjecting sufficiently large portions of its members to sufficiently burdensome collateral consequences, even if those subjected to these burdens are better off than they would be in the state of nature.

An alternative account of political legitimacy contends that it derives from the consent of the governed. Attempts to ground legitimacy in express or tacit consent encounter the objection that in actual political communities, few members have consented in these ways to state coercion. This has led some theorists to ask instead whether hypothetical individuals with certain features, or individuals in certain idealized choice situations, would consent. Hannah Pitkin writes: "Legitimate government acts within the limits of authority rational men would, abstractly and hypothetically, have to give to a government they are founding. Legitimate government is government which deserves consent." ${ }^{66}$ The implications of collateral consequences for whether state coercion is legitimate on such accounts are relatively clear. If a significant number of collateral consequences constitute wrongful harms, then those inclined toward hypothetical consent views should ask whether a state whose legal system imposes these wrongful harms on a substantial portion of its members (or is unwilling or unable to protect them against such harms) is a state that deserves consent.

Thus on at least two predominant accounts of political legitimacy, the existence of widespread collateral consequences arguably undermines the legitimacy of state coercion. There are other accounts of political legitimacy on offer, and a diverse range of accounts within the benefits and consent views. But the problem posed by collateral consequences for legitimacy will generalize. On any plausible account of political legitimacy, a state's legitimacy will be compromised when it subjects large portions of its populace (or is unable or unwilling to prevent their being subjected) to a host of wrongful harms.

\section{Conclusion}

I have not demonstrated in this chapter that all or even most collateral consequences constitute wrongful harms (although I have suggested that many do). Rather, my point has been that if these consequences constitute wrongful harms, then they are salient to our conversations about justified criminalization. They are relevant, first, to determinations of what types of conduct a state may criminalize, and second, to assessments of whether a state may legitimately criminalize conduct at all. This means that normative analysis of collateral consequences, which is important in its own right, is also needed because of its implications for the issue of criminalization. Compared with the enormous amount of

65 Ibid., p. 237.

66 Hanna Pitkin, “Obligation and Consent-I,” American Political Science Review 59(4) (1965): 990-999, p. 999. For an alternative formulation of a hypothetical consent view, see John Rawls, Political Liberalism (New York: Columbia University Press, 1993), esp. p. 217. 
attention moral and legal philosophers have for centuries devoted to the justification of legal punishment itself (that is, to the formal sentences imposed on offenders), and more recently to questions of justified criminalization, the permissibility of collateral consequences has received relatively little consideration. I suggest it is time for this to change.

Open Access This article is distributed under the terms of the Creative Commons Attribution 4.0 International License (http://creativecommons.org/licenses/by/4.0/), which permits unrestricted use, distribution, and reproduction in any medium, provided you give appropriate credit to the original author(s) and the source, provide a link to the Creative Commons license, and indicate if changes were made. 